\title{
Regulation of Land Use Rights After the Job Creation Act
}

\author{
Ummy Ghoriibah $^{1}$, Elita Rahmi ${ }^{2}$, Yetniwati ${ }^{3}$ \\ ${ }^{I}$ Notary Study Program, Faculty of Law, Jambi University \\ ${ }^{2.3}$ Universitas Jambi, Indonesia \\ ummy1001@gmail.com
}

\begin{abstract}
The extension of the term of the Land Use Rights (HGU) after the Job Creation Act which extended the tenure of HGU to 95 years created a conflict of norms with Law Number 5 of 1960 concerning the UUPA. The uncertainty of the time period will cause many problems regarding the extension of the HGU that has been granted by the government. Especially for HGU on land that will expire, whether the National Land Agency (BPN) will refer to the UUPA or the Job Creation Act. PP Number 18 of 2021 concerning Management Rights, Land Rights, Flat Units, and Land Registration. Article 22 stipulates that Land Use Rights are granted for 35 years and extended for 25 years and renewed for 35 years, the total HGU being 95 years. The history of HGU during the colonial period is feared to exacerbate the economy of the poor, between the rich and the poor, whose access to natural resources is far from the aspect of justice. This difference is certain to cause a lot of conflict between companies and the government, companies and communities, and even between communities with one another. The research method used is a normative juridical approach with a history approach, a concept approach, and a futuristic approach. Conclusion The difference in the time limit for Cultivation Rights will cause quite a big conflict for the development of Agrarian Law in Indonesia, if it is not carried out with a local wisdom approach and regulations regarding the inclusion of venture capital in companies (inbreng).
\end{abstract}

Keywords- Regulation, Land Use Rights, After The Job Creation Act.

\section{INTRODUCTION}

Land Use Rights (HGU) is a land right that causes a lot of agrarian conflicts in Indonesia, the contributing factor is the area of land granted through land rights reaches hundreds or even thousands of hectares and the length of time given by the Law on land tenure reaches 95 years based on This work copyright law is the cause of social jealousy for the community around the plantation land, and has even dragged landowners in the village into land laborers.

The history of HGU land since the colonial era has become a tool to control the colony through the domain principle, where people who cannot prove that the land is theirs, then the land is the land of the colony (the Netherlands), the history of dualism in land law in Indonesia, where Bumi Putera subject to customary law can certainly not prove the land belongs to him. It turns out that until this reform era, the politics of the domain continued through extensive and long-lasting land tenure.

The sensitivity of HGU land in Indonesia must not repeat the colonial policy to control people's land. Since ancient times, this HGU has been a problem because it was used as a colonial policy to control the land, so the so-called HGU Land was established, so that it could control the land for a long time and was very wide. Supposedly when we are already independent then in fact this HGU land must be clearly and firmly limited in the laws and regulations so that the access of the small community can answer the question of substantive justice to access to natural resources.

The history of this HGU, with the Law on Investment No. 25 of 2007 on the Constitutional Court Decision 2122/PUU-V/2007 should be a lesson that this long grace period raises doubts for the people to control the land. This means that the HGU land can cause structural poverty for the surrounding community. Now in the Employment Creation Act, the regulation of the long grace period is re-arranged as was the case during the Investment Law. We have a history since colonial times that the regulation that is too long and too broad creates injustice in access to natural resources. The difference in the amount of area is what causes social jealousy. So it's as if the Job Creation Act is repeating the domain principle during the colonial period.

The national land law contained in Law Number 5 of 1960 concerning Basic Agrarian Regulations, or better known as the Basic Agrarian Law (UUPA) regulates land tenure rights. Boedi Harsono stated that land tenure rights contain a series of powers, obligations, and or prohibitions for the holder of the right to do something about the land that is their right. Something that is allowed, obligated, or prohibited to be done, which is the content of the right of control is the criteria or benchmark for distinguishing between the rights of control over land regulated in the Land Law. [1]

Hierarchically, land tenure rights consist of Indonesian rights to land, state control rights over land, customary rights of customary law communities, and individual rights to land, including land rights, mortgage rights, and waqf land. Land Use Rights (HGU) in Indonesia is regulated in the Basic Agrarian Law (UUPA) Number 5 of 1960 explaining Article 28 paragraph 1 which stipulates that the right to cultivate land is controlled directly by the State, for agricultural, fishery or livestock companies. Which is continued in Article 29. The 
arrangement for the extension of the HGU is granted for 25 years and extended for 35 years and renewed for 25 years, the total HGU being 85 years.

Cultivation rights over land regulated in the Basic Agrarian Law (UUPA) whose time period has changed from the basic concepts and rules in the UUPA, problems arise in terms of extending the term of the HGU which occurs between the UUPA as a law and a number of regulations in underneath. PP Number 18 of 2021 concerning Management Rights, Land Rights, Flat Units, and Land Registration is a derivative rule from the provisions of Article 142 of Law Number 11 of 2020 concerning Job Creation Act which states that further provisions regarding management rights are regulated in a Government Regulation. Where previously explained in Article 129 Land managed by the land bank agency is given management rights.

The right of control over land contains the authority, obligation, and prohibition for the holder of the right. There are land tenure rights that are private, namely ownership, and some are public, namely regulating and determining. There are land tenure rights which are legal institutions, which have not been linked between the land and certain legal persons or entities as the holders of their rights, and there are concrete legal relations, which have been linked between the land and certain legal persons or entities as the holders of the rights.

September 24, 1960 became the point of the rise of national land law after the approval and ratification of Law Number 5 of 1960 concerning Basic Regulations on Land Principles or it could be called the UUPA. The birth of the UUPA as a marking the end of the dualism of land law in Indonesia, which originally originated from colonial law and customary law, which was changed to a national land law and a democratic and populist land structure. Fundamental changes are characteristic of the UUPA which automatically revokes Agrarische Wet. [2]

Policy makers give a high bargaining position to the UUPA, because in the 1945 Constitution it is the main rule that becomes a reference for other regulations that overshadow and regulate the earth, water, and space, Article 33 paragraph (3). Although the object of regulation of the UUPA also mentions Articles 1 and 2 covering earth, water, and space, most of the articles regulate land, so the UUPA is often referred to as the Land Law.[2]

The State is the highest authority organization for the entire Indonesian people (nation) as the governing body that regulates the allocation, use and use of land. , and land use in Indonesia. In its journey, because the UUPA regulates land affairs only in basic matters, so that it is deemed necessary to have an implementing regulation that functions as a complement and at the same time completes the substance of the UUPA, This is due to the increasing need of the Indonesian people for legal certainty which must be in line with the basic principles in the 1945 Constitution of the Republic of Indonesia and the UUPA.

The land bill is not intended to replace the UUPA,but is lex specialis,and he UUPA becomes lex generalis,so that the land bill is expected to be able to realize a complete and clear national land system, and be guided by the principles underlying the UUPA and the principles contained in the MPR TAB. Number IX/2001 regarding land reform and natural resource management, where this stipulations is the final result of the hopes and demands of the people,especially the peasants, to managing the nasional land " treasure" policy in accordance with the ideals of the UUPA, which during the the regime the new order was ruled by the ruling party.

The Land Bill was originally ratified on September 24, 2019 , however, its ratification was officially canceled and will be discussed again during the leadership of the next legislative member. President Joko Widodo has signed the Omnibus Law on the Job Creation Act on Monday, November 2, 2020. Thus, all provisions in the Law on Job Creation come into force on November 2, 2020.

In fact, the UUPA is more oriented towards conservation (maintenance), taking sides with the people, and recognizing and respecting the existence of indigenous peoples in Indonesia. Meanwhile, the Sectoral Law on Natural Resources Management (PSDA) is more oriented towards exploitation (utilization), more in favor of capital (investors/investors). The factor that caused the dispute was that the UUPA and the PSDA Sectoral Law did not have the same principle. The difference in principle occurs because the UUPA in its position as the parent for the PSDA Sectoral Law is not used as a reference in the formation of the PSDA Sectoral Law formulation.[3]

\section{RESEARCH METHOD}

The method used in this research is a normative juridical research method that places the law as a system of norms which is the basis for the birth of binding regulations to carry out the rights and obligations as lawabiding citizens. The subject of the study is the law which is conceptualized as a norm or rule that applies in society. This study focuses on an inventory of positive law, legal principles and doctrines, legal findings in cases in concreto, legal systems, synchronization levels, legal comparisons and legal history. The main source of data in this research comes from secondary data, obtained through document/library research (library research). The data collection technique is using a documentary study, which is a study that examines various documents related to the subject matter for in-depth elaboration.[4] To do study, used 4 approach as follows: Historical Approach, Statute Approach, Conceptual Approach, and Futuristic Approach.[5]

\section{FINDINGS AND DISCUSSION}

\section{Dynamics of Land Use Rights Regulation in Indonesia}

Since the Dutch East Indies became a Dutch colony (1815), the legal conditions, especially civil law, have been dualistic. The political domain owned by the colonizers influenced the applicable law, because a very 
wide political area could change the legal provisions that had been in force under colonial rule.[6]

Access to the laws imposed by the colonizers often made the indigenous population feel unfair treatment in the eyes of the colonial law, this made the indigenous people often feel annoyed with the colonial government. According to the Article imposed by the Dutch-Indies government, there is an article regarding population groups, namely Article 163 I.S.

Based on Article 131 paragraph 2 sub b. Indische Staatsregeling (I.S.) and Article 15 of Algemene Bepalingen van Wetgeving (A.B.) for native Indonesians in the field of private law (civil) apply especially customary law. However, there is a possibility to deviate from customary law, if it turns out, that the deviation needs to be related to social needs or in the public interest. The existence of the dualism of civil law was also followed by the dualism of land law.

Submission land country for given in form HGU to Inhabitant Indonesian country based on decision gift right in Thing this Minister agrarian and System Room or office others who appointed in affairs defense. In Article 28 set that land use rights is right for strive land which mastered direct by Country, in period time as the in article 29, To use company Agriculture, fishery or farm. Land Use Rights given on land which breadth most a little 5 hectares, with provision that if breadth 25 hectares or more must use investment capital that worthy and technique company which good, in accordance with development era Land Use Rights could switch and diverted to party other.

According to the provisions of the National Land Law, companies with the status of Indonesian legal entities including PT PMA (Foreign Investment) can control the land according to its designation with the following rights:

1. Building Use Rights (HGB) for housing, industry, and others in the context of the function of land as a container.

2. Land Use Rights for agriculture, fairies, plantations and livestock.

3. Right of Use (HP) for agricultural and nonagricultural purposes.

4. Management Rights (HPL) specifically for StateOwned Enterprises.

At the time of the Foreign Investment Law (PMA) the plan to realize the length of grace period for the control of HGU Land already existed through article 22 letter a but was later sued based on the decision of the Constitutional Court 21-22/PUU-V/2007 The Indonesian Constitutional Court disappeared and reappeared in the Job Creation Act. 2020 work.[8] The government through PP Law Number 18 of 2021 concerning Management Rights, Land Rights, Flat Units, and Land Registration is a derivative rule from the provisions of Article 142 of Law Number 11 of 2020 concerning Job Creation, it is stated that further provisions regarding management rights regulated in a Government Regulation.

(Law) Number 11 of 2020 concerning Job Creation has extended the period of land management with the status of Land Use Rights to a maximum of 35 years from the previous 25 years. After 35 years of management, HGU land owners can even extend the management period for a maximum of 25 years and can also be renewed for a maximum of 35 years. So that the total term of HGU management can reach a maximum of 95 years, through Government Regulation (PP) Number 18 of 2021 concerning Management Rights, Land Rights, Flat Units, and Land Registration as regulated in Article 22 Paragraph 1. HGU holders are regulated in Articles 27 and 28. [9]

HGU Extension Article 26 Paragraph (2) PP Number 18 of 2021, namely the application for renewal of cultivation rights shall be submitted no later than 2 (two) years after the expiration of the term of time HGU. Problems with Substance of Agrarian Policy in the Job Creation Act UU no. 11 of 2020 concerning Job Creation is a form of Omnibus Law implemented in Indonesia. Omnibus law is the concept of simplifying various legal products into one comprehensive legal product. The Job Creation Act related to the agrarian sector is contained in Chapter VIII of Land Procurement with the aim of how to provide land for various interests in order to support investment for job creation. In CHAPTER VIII of land acquisition, there are 3 parts, namely Land Acquisition for Development in the Public Interest (Ps. 123), Land Protection for Sustainable Food Agriculture (Ps. 124), and Land (Ps 125-147).[10]

There are 2 (two) agrarian-related laws whose substance was revised, revoked and/or strengthened for the benefit of large investors, namely Law no. 2 of 2012 and Law no. 41 of 2009. In addition, there are several new norms that are included in Law no. 11 of 2020. The preparation and discussion of Law no. 11 of 2020 which is not implemented with the principles of transparency and democracy guaranteeing active public involvement has caused various problems in its substance.

\section{Various Problem of the Substance of Agrarian Policy in the Job Creation Act}

Regarding the regulation of land acquisition policies for development in the public interest in Law no. 11 of 2020 includes accelerating the land acquisition process and expanding the category of land for the public interest by adding upstream and downstream areas for the oil and gas industry, industrial estates, SEZs, tourism areas, industrial areas, technology development areas. This means the entry of investors in the five areas of the area in the category of public interest. On the one hand, it does not include the agrarian reform agenda in the category of public interest. The development of the five areas has an effect on pro investment. So there is a blurring of the benchmarks for public interest should be.[11]

Procurement of land less than 5 ha can only be done by people who have rights. After location determination, EIA is no longer needed. In Law No. 11 of 2020 it is stated that the amount of compensation based on the results of the Appraiser's assessment is final and binding. 
So the provisions in the Job Creation Act prioritize efficiency but seem centralized. The Job Creation Act regulates for the development of common interests and for national strategic projects, agricultural land use can be changed. This we know that the category of public interest is getting wider and there are no provisions in the explanation of what is included in the national strategy project. This further increases the conversion of agricultural land in the name of investment and development.[12] The conversion of agricultural land causes the area of rice fields to be threatened with decreasing. Even though the area of rice fields continues to decrease every year.

\section{Land Bank}

Land bank agencies have an important function in land acquisition planning to land distribution from state interests to agrarian reform. Land Bank Agency is nonprofit. This non-profit BBT is because the government that builds the reserve land it owns still carries a development mission and the public interest.[13] The authority of the land bank agency as an autonomous legal entity as well as the private sector by being able to determine service rates and receiving capital participation from other parties can potentially be misused by business people in order to obtain ease of land acquisition. So that the non-profit principle owned by the land bank is lost.

Land managed by the land bank agency is given a management right which can grant a hak guna-usaha (HGU). The granting of HGU from land with management rights is not in accordance with Article 28 and Article 2 of Law No. 5 of 1960 (UUPA). The Basic Agrarian Law regulates the origin of HGU land, namely state land. In addition to the Job Creation Act, the period of HGU from management rights is not regulated with certainty. According to Prof. Maria SW Sumardjono, the more authority possessed by the holder of the management right, suggests that the position of the management right emphasizes more on its civil nature than its public function. The public function of management rights has deviated from the purpose of granting management rights.[14]

Differences in perception regarding the status of HGU land that has expired The timing started with different perceptions about state land. Role of Notary/PPAT Making a binding deed of sale and purchase also plays a role in anticipating the emergence of disputes from the binding deed of sale and purchase of land rights, namely in its manufacture it must be equipped with power of attorney, among others, the power to sell, absolute power, power to guarantee. Then proceed with the PPAT transfer deed, namely the deed of change of the company. Role BPN With the partial separation application process HGU until the publication Partial release permit issued by Head Office Regional Land.

On Article 720 of the Civil Code reads: Cultivation rights are material rights to fully enjoy other people's immovable property, with the obligation to pay an annual tribute to the land owner, as an acknowledgment of ownership, either in the form of money or in the form of proceeds or income. The basis for the birth of the right to cultivate must be announced in the manner as specified in Article 620.

Sporadic land registration is a land registration activity for the first time regarding one or several objects of land registration within the territory or part of the territory of a village/kelurahan individually or in bulk. Land registration data maintenance activities are able to adjust physical data and juridical data in registration maps, land registers, name lists, measuring documents, land books, and certificates with changes.[15]

The Job Creation Act does not mention or does not base this provision with the UUPA, this will become a legal problem in the future. So it turns out that the HGU is now being developed in the job creation act but unfortunately the job creation act does not refer to or is not based on the UUPA. If there is a problem, it can be ascertained that there will be multiple interpretations. The HGU is now interestingly there is another HGU on HPL land so there is a HGU certificate and a HGU certificate on HPL land.

The principle of horizontal separation is the principle which states that buildings and plants on the ground are not part of the land, between land and objects on it can actually be regulated by a new law. Land rights do not necessarily include ownership of buildings and plants on them. Legal actions regarding land do not necessarily include legal actions against buildings and plants. The plasma system that causes farm laborers for the surrounding community is due to changing land owners into land laborers.

One of the results of research on plasma systems as a form of collaboration between companies and the community as stated by Ahuja (1997) shows an imbalance between population and the availability of resources (land and capital). The consequence of this condition is that investment growth (total) is low and limited to the relatively small number of individual farmers who own certain lands. The next consequence is that capital growth will remain smaller than population growth, so that there are not enough job opportunities to accommodate productive workers. Moreover, the hope of workers to find work outside the plantation is also constrained by limited productive resources.

This condition will further lead to unemployment and poverty. In a situation like the one above, productive workers will inevitably work on plasma plantations with their families. The addition of this workforce did not increase rubber production. This condition gets worse if other production factors (land, technology and capital) remain constant (no change). The labor activities in the plasma plantations can then be interpreted as working together with the family which has an impact on decreasing working hours and work intensity. In this situation, they do not apply the economic principle in the use of labor, namely the marginal product of labor is not equal to the wage rate. In economic terms, this kind of condition is known as invisible unemployment (disguishedunemployment). 
The logical consequence of subtle unemployment is a decrease in the standard of living. If this situation is left without a basic solution, the next consequence is what is called a circle of poverty. The Plasma system creates land conflicts for the surrounding community, it is better to get rid of it because it causes land workers on their own land. The local wisdom approach can be interpreted as a view of life and local knowledge created from the adaptation of a community that comes from life experiences that are passed on from generation to generation in the community.

Things that are rarely discussed about oil palm plantations need to be known together that, oil palms live from 30 years to 33 years and will die. Now, it causes further problems if the fibrous roots are planted at a distance of 10 meters from the ground, thick roots will grow as deep as 2 meters underground and it cannot be planted anymore. How to destroy the thick fibrous roots? and kill the pests that live at the tips of those fibrous roots? Who is responsible for that / Laws are made to restore land or regenerate land to make it useful again.

After the palm is approximately 33 years old, it will die. The thickness of the fibrous roots is 2 meters in the ground, that is, if 1000 hectares are planted, then 1000 hectares in the 2 meter depth of soil are all thick roots. Now at the end of the fiber roots in the soil, pests live. If we plant trees there. Pests at the tip of the palm roots will move to the roots of the newly planted tree, so that the newly planted tree will eventually turn yellow and die. The impact of this oil palm plantation is also that the water becomes dry. There is no water around because the water dries up.

\section{CONCLUSION}

We have to go back to the UUPA that the HGU arrangement is in short order. There are terminated legal consequences of 25 years, extended 35 years, renewed 25 years. And gradually the Government should limit what percentage is actually the area that can be used for HGU. The majority of areas in Sumatra and Borneo are actually HGU lands that are larger than government lands. So that in fact the ruler in the area is actually the owner of the HGU, not the local government.In fact, the rulers of the land are the subjects of the HGU. That which causes conflicts in the future must be limited, for example $15 \%$ or $25 \%$ or $35 \%$. Inbreng or modal participationl as a solution to the HGU land conflict to society. Transaction inbreng is a transaction for the company's capital participation which can be in the form of assets such as land, buildings, and other assets. The Job Creation Act aims to establish an investment ecosystem both from within and outside the country. The agrarian policy in the Job Creation Act is to provide land for various purposes in order to support investment for job creation. It's just that there are still some controversial substances that cause rejection from various circles. The controversial substances include (1) the entry of investors in the fields of mining, industry, tourism, special economics, technology in development. (2) LP2B can be converted to public interest and national strategic projects. (3) establishment of a land bank that is autonomous and has management rights (4) strengthening of management rights that can provide land use rights with an uncertain time limit (5) foreigners have ownership rights to flats, (6) The granting of rights as well as the extension of HGB for flats after obtaining a certificate of proper function, (7) providing a strong legal umbrella in granting rights to upper and lower land spaces for businesses. Potential impacts on agrarian reform performance include increasing agrarian conflicts, Land Bank overlapping with the Agrarian Reform Task Force.

\section{REFERENCES}

[1] Sudaryatmi, Sri (2000) Penentuan Hak Dan Pemanfaatan Tanah Timbul Dalam Icaitannya Dengan Pengembangan Ekonomi. Masters Thesis, Program Pasca Sarjana Universitas Diponegoro.

[2] Liadi, W. S. (2019). Kedudukan Eigendom Verponding Dalam Hukum Pertanahan Di Indonesia. Jurnal Panorama Hukum, 4(1), 11-18.

[3] Elisabet S, Romasta (2020) Analisis Yuridis Sertipikat Hak Milik Yang Berada Di Atas Tanah Hak Pengelolaan Menurut Hukum Tanah Nasional. Masters Thesis, Universitas Pelita Harapan.

[4] Indra, Haditama (2017) Implementasi Batas Penguasaan Dan Kepemilikan Atas Tanah Perorangan Dalam Perspektif Fungsi Sosial Berdasarkan Peraturan Kepala Badan Pertanahan Nomor 6 Tahun 1998 Tentang Pemberian Hak Milik Atas Tanah Untuk Rumah Tinggal. Masters Thesis, Ilmu Hukum S.2.

[5] Rahmi, Elita. Sayuti, Triganda Ageng. \& Fadli, Zul. (2019). Klausul Tanggung Jawab Sosial Dan Lingkungan Dalam Akta Notaris Sebagai Upaya Pengembangan Perusahaan Terbatas (PT) Pada Era Globalisasi. Recital Review:Vol. 1 No. 1 (2019): Volume 1, Issue 1, Januari 2019, 108-136.

[6] Prabowo, Adhi (2020) Rekonstruksi Pengaturan Perolehan Hak Atas Tanah Untuk Investasi Pada Era Otonomi Daerah Berbasis Nilai Keadilan Sosial. Doctoral Thesis, Universitas Islam Sultan Agung Semarang.

[7] Lisdiono, Edy. 2008. Legislasi Penataan Ruang : Studi Tentang Pergeseran Kebijakan Hukum Tata Ruang Dalam Daerah di Kota Semarang. Fakultas Hukum UNDIP.

[8] Manan, Bagir.1997. Beberapa Masalah Hukum Tata Negara Indonesia. Bandung: Akumni.

[9] Santoso, Urip. 2017. Hukum Agraria Kajian Komprehensif . Jakarta: Kencana.

[10] Sihombing, B.F. 2018. Sejarah Hukum Tanah Indonesia. Jakarta, Prenadamedia Group.

[11] Sofyan A. Djalil. 2020. Kebijakan Tata Ruang dan Pertanahan dalam RUU Cipta Kerja.

[12] Sumardjono, Maria SW. 2018. Regulasi Pertanahan \& Semangat Keadilan Agraria. Yogyakarya: STPN Press.

[13] Wardani, Dwi K. 2020. Disharmoni Antara RUU Cipta Kerja Bab Pertanahan dengan Prinsip - Prinsip UU. No.5 Tahun 1960 Tentang Peraturan Dasar Pokok-Pokok Agraria (UUPA). Jurnal Komunikasi Hukum (JKH) Universitas Pendidikan Ganesha, Vol 6 No 2: 440445.

[14] Sakti, T. (2019, 24 Desember). Penataan Hak Guna Usaha Untuk Kesejahteraan Masyarakat.

[15] Rahmi, Elita. 2011. Hukum Pertanahan Dalam Sistem Hukum Indonesia. Bandung: UNPAD PRESS. 